\title{
Faculty Members' Attitudes towards the Performance Appraisal Process in the Public Universities in Light of Some Variables
}

\author{
Wafaa Mohammed Ali Al-Ashqar ${ }^{1}$ \\ ${ }^{1}$ Irbid National University, Jordan \\ Correspondence: Wafaa Mohammed Ali Al-Ashqar, Irbid National University, Jordan
}

Received: November 18, 2016

Accepted: December 30, 2016 Online Published: May 29, 2017

doi:10.5539/ies.v10n6p135

URL: https://doi.org/10.5539/ies.v10n6p135

\begin{abstract}
The present study aimed to detect the level of faculty members' attitudes at public universities towards the performance appraisal process and its relationship with some variables (gender, college, scientific rank, university, teaching experience, and age). The study sample consisted of (320) faculty members of both sexes in three public universities in northern Jordan, namely (Al Yarmouk University, Jordan University of Science and Technology, Al-Balqa Applied University). The results showed that the attitudes of faculty members towards the performance appraisal process was moderate, and the results showed that there were no statistically significant differences at the significance level $(\alpha=0.05)$ in the degree of attitudes of faculty members towards the performance appraisal process in the public universities due to gender, college, scientific rank, teaching experience, and age. As for the university variable, the differences between the averages were not statistically significant.
\end{abstract}

Keywords: faculty members' attitudes, public universities, performance appraisal process

\section{Introduction}

Universities play a vital role in all parts of the world by participating actively in establishing the knowledge of societies, which ultimately leads to the rapid economic growth, and that the universities in any country working on human capital development (students) to contribute to the best in the various professions and the society as a whole. Universities are responsible for the development and success of open and democratic civil society, which gives students insight and reflect the theme of knowledge as well as to provide social skills of communication and interaction, to prove that it is a model of a modern civil society and a good place for education.

Moreover, the universities share work between the faculty member and administration together, but the primary responsibility for the development of students professionally comes at the hands of a faculty member. Perhaps the achievement of global standards and effective management, and the good performance of the faculty members constitute a major concern in any university. The sustainable process of performance evaluation of faculty members at universities should be poured into its main interest that operate in turn to enhance the performance of students and improve education and training for them as the next human capital. The blossoming of learning and enrich the academic and intellectual knowledge to students in the university environment as a whole and the quality of higher education in universities cannot be achieved without evaluate and continuously improve the performance of the teacher (Ibrahimi, 2013).

The performance of the faculty member related to the society around him such as spreading culture, counseling and conduct studies and research that address the problems of the society as well as to strengthen the relationship of the university community institutions and activating the role of government and private institutions in the University Student Service (Kubaisi, 2010).

The university professors' tasks are achieved through the development of students to participate actively in the tremendous knowledge management theory and relevant context, and this matrix of tasks for university professors make them more practical and renewal. Professional development for university professors requires a system for assessing the effective performance during their careers (Aslam, 2011).

Stronge (2006) explains different types of methods of assessment such as assessment of institutions or students or assessment by peers, but all these methods aim to identify the gap between performance and provide opportunities to overcome these gaps in the colleges of higher education (Sheikh, 2007). We must encourage 
faculty members to perform evaluation because of its convenient positive results, and improve effective teaching process on a larger scale, where it leads ultimately to increased insight to those responsible for the university to prioritize on the learning environment and create an atmosphere better education for students (Reddy, 2006).

The performance evaluation process is seen as the teacher's guide in order to improve his ability to teach in order to give the best of what he has, and faculty members need more accurate and valid data for self-improvement in weak points, when the evaluation based on facts faculty members will have better measures of positive improvement. This means that the performance of faculty evaluation system must transfer teachers to improve teaching methods and bring about the desired change and increase productivity by improving the weaknesses pointed out by the results (Aslam, 2011).

Peterson (2000) confirms that there is compulsory and multi-tasks as an idea of accountability to ensure that the teacher offer the services according to the requirements of the enterprise, and improving performance leads to professional growth and improve the performance of teachers. Stronge (1995) also confirms that the accountability and performance improvement is supportive interests are inevitable to develop and enhance the delivery of educational services, and there must be cohesion between the various tasks and evaluate teacher performance. This multi-tasking is one of the evaluation processes, and the improvement in this aspect is not limited to the teacher only, but to improve the university as a whole, and that the goal of performance in universities evaluate is to reach decisions on personnel such as promotion, decisions to get performance bonuses, and guidance in hiring decisions or termination.

There are many methods for evaluating the faculty members such as Likert Scale in the questionnaires which is designed to evaluate the performance, then extract the means and use it as an indicator of performance. Formative evaluation or summative through collecting assessments and express it as a percentage of the general classification, then ask questions for students to evaluate the overall performance (Davies, Hirschberg, Lye, Johnston, \& McDonald, 2007).

\section{Ways and methods of performance evaluation}

There are many methods and techniques used in the performance evaluation of faculty members and the most important of these methods and techniques include:

\section{First: traditional way}

1) Gradient graphic way: It is a measure consists of several estimates begin with low-grade and end high estimate, as if the estimates (low, moderate, good, very good, excellent) and expressed in numbers, and then those estimates are combined and the total is a representative of the level of the screened individual.

2) Sort method: The personnel order the subjects belonging to him in a descending order from best to worst in the way. The basis for the ranking is the overall performance of the work and not the characteristics or certain qualities, this method can be learned and applied more easily in the case as the number of faculty members are few and does not exceed twenty individuals (Shawish, 2005).

3) Forced distribution method: to compel the administrator or department head on the distribution of faculty members on the ratings are determined by the university, which is called the normal distribution. Since the majority of faculty members are taking an intermediate degree of assessment, the proportion of members is taken whenever a departure from this intermediate class either rise or fall (Maher, 1999).

4) Evaluating method through freedom of expression: This method relies on what is he doing, in charge of writing his impressions about the faculty member. Not using tables and there are not specific lists or any other means, and these impressions can be arranged as headings subset, such as: the nature of the assessment of the task, recipes of faculty member, things that need to be developed and others (Shawish, 2005).

5) Dual comparison between the workers: the administrator compares the performance of each faculty member with the other members, and by dividing the members of their departments into pairs. This method provides dramatic objective. It is a complex process in the case of large numbers and weaknesses and shortcomings appear in the performance of a faculty member.

6) Checklists: This method is based on studying each type of jobs, and selecting the questions that include descriptive phrases which describe good performance. There is no specific number, but the number depends on the job and its nature, the official answer to the questions "yes" or "no" according to what applies to a faculty member to be evaluating his performance. Then combining grades obtained by the faculty member after the completion of the answer and turn it into a descriptive value to reflect his performance (Abu 
Sheikha, 2000).

\section{Second, modern methods of performance evaluation}

The traditional way of evaluation was criticized because of its reliance on the personal characteristics of the officials and heads of departments and prejudices rather than reliance on the objectives to be measured for performance, so thinking to develop better ways to assess the performance of faculty members has been started (Abdelbaki, 2000), and these methods include:

1) Critical incidents method: This method relies on the collection of facts affecting the performance of a faculty member, and then the administrator observing the performance to know exactly what the facts that happened to carry out his duties and responsibilities of the job, and after the performance is evaluated based on the number of incidents that have occurred in the performance

2) Compulsory selection method: This method to choose the president in charge of ferries two phrases from four phrases describe a faculty member, and one to be the best he has had and the other will be far from the description, and this way is characterized with objectivity in the evaluation, and is characterized by forcing resident to study the performance accurately and analyze phrases to find out the extent of overlap between the behavior and characteristics of a faculty member (Abu Sheikha, 2000)

3) The way of field research: it depends mainly on the active participation of the management of faculty members in the performance appraisal process. And it is based on an oral procedure during the interview and is then formulating answers and a written description, and the members are assessed on the basis of the order of one estimate (excellent, good, acceptable, unacceptable).

4) Collective assessment method: The Members performance evaluation by the Commission, one of its members have a direct head of a faculty member, and after the meeting, some things will be discussed as standards of performance, and the completion of the same group and private business to improve its performance in the future.

5) Evaluation based on results: based on the idea of the progress made by the faculty member from the results as a basis for evaluating performance, and focusing on specific safeguards provide them with objectivity in the assessment, develop a spirit of cooperation between the President and his subordinates.

6) Style of management by objectives: This method is based on the idea of the involvement of faculty members with their boss in setting goals and achieving and completing them, and this method has become commonly used in recent years (Shawish, 2005).

The evaluation of effective comprehensive teaching must be fundamentally conducted on certain principles to reach the designed goal of the foundation and the evaluation must be the best possible measure and an essential part of the educational process. Collecting data for scientific assessment should be clear and accepted by both students and teachers. it is a must for every student to give a fair and realistic reaction to teacher performance inside the teaching hall, and here is the responsibility of the teacher to make efforts for a better learning environment and improve himself for effective teaching (Reddy, 2006). It must be considered that both the students, colleagues, administrators, and the teachers themselves are key elements in the collective judgment of the performance of teaching. Actually, the students are always able to provide the correct information about teachers' performance, and effectiveness in teaching, and the co-teachers in the same job for them positive evaluation process contributions. The teacher's evaluation of himself also is instrumental if conducted properly and in a constructive way to be an inherent part of the evaluation and effective information to improve performance (Seldin, 1980).

\subsection{The Problem of the Study and Its Questions}

Universities in various countries are seeking to gain access to advanced ranks in the classification of international universities, the evaluation process is used as one of the things for organizational restructuring to access advanced mattresses. Public universities' administrations in Jordan assess performance of faculty members periodically, it is semi-routine process that is not used in achieving the desired goals, and the university departments do not benefit from the evaluation process to take appropriate decisions as a contract training courses inside or outside the university, or the granting of physical or moral bonuses and rewards. This makes the evaluation process has no role in the work of faculty members. Some parties may do this process also subject to prejudices and personal relationships, and the assessment of teachers randomly. Hence, the problem of the study appeared which is the attitudes of faculty members about the performance appraisal process in the public universities, the study attempts to answer the following questions: 
1) What is the degree of the attitudes of faculty members about the performance appraisal process in public universities?

2) Are there significant differences at the significance level $(\alpha=0.05)$ in the attitudes of faculty members according to gender?

3) Are there significant differences at the significance level $(\alpha=0.05)$ in the attitudes of faculty members depending on the college variable?

4) Is there a statistically significant differences at the significance level $(\alpha=0.05)$ in the attitudes of faculty members depending on the variables of scientific rank, university, teaching experience, or age?

\subsection{Significance of the Study}

The importance of the study from the theoretical aspect appeared by identifying the degree of attitudes of the faculty members about the evaluation process in universities in northern Jordan, and its implications on the professional status of workers in these universities, and its role in stimulating or not to stimulate the performance process of the faculty member. From the practical side, the study is working to provide the managers of these universities and the Ministry of Higher Education with the results. This will help them to shape the future plans of these universities and develop to reach the advanced levels at the level of higher education institutions, as this study provides important data to improve the performance of faculty members and the progress they have of their better performance.

\subsection{The Objectives of the Study}

This study seeks to achieve the following objectives:

1) To detect the level of the attitudes of faculty members in governmental universities towards the performance appraisal process

2) To identify the differences between the attitudes of faculty members according to gender

3) To identify the differences between the attitudes of faculty members depending on the college variable

4) To identify the differences between the attitudes of faculty members depending on the variables of scientific rank, the university, teaching experience, and age.

\subsection{Procedural Definition of Terms}

Attitudes: it is a state of psychological readiness and be a guideline or a dynamic effect on the individual for all subjects and situations that evoke this response (O'Keefe, 2002). Moreover, it is defined procedurally through grade the obtained from the questionnaire prepared for measuring faculty members attitudes.

Faculty members: they are qualified and efficient personnel to carry out the educational process within the college within the framework of his university, and are working on a follow-up study plans for programs and disciplines and development, which is in charge of supervising the students.

Performance: The evaluation of a system designed to measure the performance and behavior of individuals while working through continuous and systematic observation to get an estimate of the effort, activity, and behavior, and the efficiency of each individual separately, so that it is all done objectively to determine the strength and promotion points and vulnerabilities and encountered the (Sabah, 1997)

Public universities: it is one of the public universities of the Jordanian Ministry of Higher Education, which are located within the province of Irbid in northern Jordan.

The limits of the study

1) This study was limited to public universities in Irbid Governorate and did not include the rest of the public universities in Jordan, so the generalization of findings should be limited to this category of universities.

2) This study was limited to faculty members in public universities at Irbid Governorate and did not include the faculty members at private universities of the same province.

3) This study was implemented during the second semester of the academic year 2015/2016.

\section{Literature Review}

Jaffery (2002) conducted a study, which aimed at identifying the views of graduate students about the teaching performance of faculty members at the University of Umm Al-Qura. The researcher used a questionnaire from her preparation, she applied it over a sample of (298) female students in the Master stage in six colleges at the University of Umm al-Qura: (Education, social Science, Applied Science, Arabic, law, advocacy). The results of 
the study indicated that there were no statistically significant differences between the mean of the responses of the students about the teaching performance of faculty members, male and female in different colleges, except Arabic language and advocacy colleges. Results also indicates the absence of significant differences between those averages about teaching performance for faculty female faculty members is due to the colleges' differences, with no statistically significant differences between the arithmetic mean of the responses of the study sample on the performance of the male faculty member is due to the different colleges.

The study of Hassan and El-Khouly (2003) aimed at recognizing different estimates of the students of the performance of faculty members at the University of Qatar according to the variables: the gender of the student and the cumulative GPA and the college where he studies, the type of the course he registered in. The study sample consisted of (2590) students and 632 faculty members. The results indicated that there were statistically significant differences in the estimates of students about the performance of the faculty members in the theoretical courses due to the gender variable in favor of male students. On the other hand, there were no statistically significant differences between the averages of estimates of students for the performance of the faculty members in the process courses due to the gender of the student. The results also found that there were statistically significant differences between the estimates of the students about the performance of faculty members in the theoretical courses, and it was attributable to the different colleges and for the benefit of both colleges: College of Education and the College of Management and Economics. There were also statistically significant differences between the means of estimates of students about the performance of the faculty members on the theoretical and practical courses due to the different colleges in favor of the colleges of education, engineering and science. While there were no differences between the students' assessments of the performance of the faculty members in the practical courses are attributable to the differences in colleges with the exception of the faculty of Engineering and the average student estimates came to perform smaller than the rest of the college.

Nono (2004) held a study that aimed to assess the evaluation of the performance of faculty members in public higher education institutions in the Gaza Strip policies, the study sample consisted of (140) Researched. Results showed that there was:

1) The system is a lack of scientific and objective criteria derived from accurate job descriptions,

2) Lack of the system to a variety of means to gather the necessary evaluation process information,

3) Process performance rests with the direct head assess located only without the participation of any other parties,

4) There is a weakness in the level of staff efficiency based on the evaluation process,

5) Feedback on the assessment results are not available, leading to ignorance of the employee's level of performance,

6) Do not rely on the assessment results in personnel decisions, such as training and motivation.

The aim of Khoury (2004) study is to determine the obstacles faced by the application of performance appraisal process of full-time faculty members in the Palestinian universities in the West Bank. The study has reached the following conclusions:

1) Performance evaluation for instructors in the university system is a traditional routine system with a slow mechanism,

2) Performance appraisal process does not have a strong impact on the teachers because there is no feedback system,

3) There was considerable support for the idea that the evaluation process of applying a better way leads to improved performance of academics.

The aim of Razek (2006) study was to detect the attitudes of faculty members of the College of Education, King Saud University, about the methods and ways to evaluate the performance of a faculty member, The study was conducted on a sample of (93) faculty members of the Faculty of Education, King Saud University. The results showed the agreement of the study sample on the importance and vitality of methods and ways to evaluate the performance of a faculty member. The order of the methods from the viewpoint of the respondents was as follows: evaluation of the heads of departments method $80 \%$, self-evaluation method $72 \%$, the way students evaluate faculty members $53 \%$; evaluating colleagues method $49 \%$. The results also indicated that there were no statistically significant differences between the attitudes of faculty members about the ways and methods of evaluation between males and females, but in the students evaluate faculty member method there were 
differences in favor of females.

The Filimban's (2007) study was aimed to know the positive and negative aspects of the academic file to evaluate the performance of the faculty members at King Abdul-Aziz University, the study sample consisted of (71) of the administrative leaders and 90 faculty members who have scientific ranks of Assistant Professor, Associate Professor, and Professor. The results showed that the evaluation played by the Vice Dean and Dean of the faculty member is not considered enough to judge the adequacy of competency and there are differences between the responses of academic leaders and faculty members in key aspects of the performance. Moreover, that some file items do not apply to the actual reality and the potential for the performance of academic profession.

The study dealt with Ajlouni (2011) tackled the attitudes of faculty members at the University of Science and Technology about the process of student assessment of their performance and the factors influencing these trends, the study sample consisted of 200 faculty members. The results showed that the personal relationships and the difficulty of Article are influencing factors in the evaluation of students' performance of faculty members. and not for the life-time of a faculty member or academic rank the impact of the trends, and the results showed no differences in these trends are attributed to the University of graduate faculty member, and did not there were differences in experience and age, academic rank variables, and that those who hold the doctorate degree more positive.

Islam (2011) study aimed to explore the performance gaps in public and private universities in Pakistan and focus on the performance of faculty members and evaluate it, the sample consisted of (100) researched divided between three layers are the deans, heads of departments, and faculty members. The personal interviews and questionnaire were used to obtain the data. The results showed that the decline in motivation to evaluate and less share in decision-making, culture and organizational competitiveness and standards of the classroom system are of the most important factors and challenges faced by universities in the performance assessment. And that the methods of performance evaluation become old and outdated decade, and the lack of training of the person is a resident of the performance hurdles for the effective performance evaluation of the system in Pakistani universities.

Moreno-Murcia, Torregrosa, and Pedreno (2015) held a study aimed to design and verify the validity of the measuring tool for evaluating the performance of teachers in the education process; the sample consisted of (1297) university students. The appropriate statistics and internal consistency have been made, and the link between each paragraph of the paragraphs. The results showed up with a suitable structure for the questionnaire consisting of three dimensions which are the planning, development, and the result, and that the tool is valid and honest in its construction to evaluate the performance of a university faculty member.

\section{The Methods and Procedures}

\subsection{Research Methodology}

In the research, the descriptive analytical method was used to determine the degree of trends of faculty members at public universities about the performance appraisal process and its relationship with some variables; where a questionnaire designed by the researcher was used to see the degree of faculty members' attitudes.

\subsection{Population of the Study}

The population of this study consisted of faculty members at Yarmouk University, The university of Science and Technology of Jordan, and Al Balqa Applied University in Irbid Governorate during the second semester of the academic year 2015/2016 and who form (1819) faculty members.

\subsection{Sample of the Study}

The study sample consisted of 320 faculty members, was chosen purposely and according to different variables of the study, and Table 1 shows the distribution of the sample according to these variables. 
Table 1. The study sample distribution according to independent variables

\begin{tabular}{|c|c|c|c|}
\hline Variable & Level & $\mathrm{N}$. & Percentage \\
\hline \multirow{2}{*}{ Gender } & Male & 160 & $50 \%$ \\
\hline & Female & 160 & $50 \%$ \\
\hline \multirow{2}{*}{ College } & Humanitarian & 160 & $50 \%$ \\
\hline & Scientific & 160 & $50 \%$ \\
\hline \multirow{4}{*}{ Academic rank } & Professor & 58 & $18 \%$ \\
\hline & Associate professor & 92 & $29 \%$ \\
\hline & Assistant professor & 103 & $32 \%$ \\
\hline & Lecturer & 67 & $21 \%$ \\
\hline \multirow{3}{*}{ Teaching experience } & $1-5$ years & 44 & $13.8 \%$ \\
\hline & $5-10$ years & 167 & $52.2 \%$ \\
\hline & 10 years and above & 109 & $34 \%$ \\
\hline \multirow{3}{*}{ Age } & Less than 35 years & 87 & $27.2 \%$ \\
\hline & $36-45$ years & 172 & $53.8 \%$ \\
\hline & More than 45 years & 61 & $19 \%$ \\
\hline \multirow{3}{*}{ University } & Al Yarmouk & 110 & $34.4 \%$ \\
\hline & Jordan university of Science and Technology & 110 & $34.4 \%$ \\
\hline & Al-Balqa Applied university & 100 & $31.3 \%$ \\
\hline
\end{tabular}

\subsection{Variables of the Study}

The study included the following variables:

First: Independent variables

- Gender: It has two categories (male, female).

- College: It has two categories (humanitarian, scientific).

- Academic Rank: It has four categories (professor, associate professor, assistant professor, and lecturer).

- University: It has three categories (Yarmouk University, The University of Science and Technology of Jordan, Al Balqa Applied University).

- $\quad$ Teaching experience: It has three categories (less than 5 years, 5-10 years, 10 years and over).

- $\quad$ Age: It has three categories (less than 35 years, from 36-45 years old, more than 45 years).

Second: The dependent variables

- The performance appraisal process

\subsection{The Study Tool}

The study tool was built by reference to the literature and previous studies on the subject of performance evaluation of faculty members such as Ajlouni (2011) study, the study of Shaheen (2010), the study of the Abu Madi (2007), and the study of Nono (2004). Then this tool was built according to a sliding scale as follows:

$(1=$ Strongly Disagree, 2 = Strongly Agree, $3=$ neutral, $4=$ Agree, $5=$ strongly agree $)$. The study tool included two parts: the first part, regards information about the independent variables of the study, namely, (gender, academic rank, university, teaching experience, age, college). Part II contained passages study tool, which has been drafted (15) paragraphs describing trends of faculty member about the performance appraisal process.

\subsubsection{The Tool Validity and Reliability}

The researcher gave the study tool to a group of arbitrators' jurisdiction who are holders of PhDs in educational research and educational supervision, to ensure its validity. They were asked to give their views on the tool, and to add what they see fit, and they were asked to express their views in the following: the extent of the paragraph clarity, and the extent of the possible presence of paragraph in the evaluation system, and the availability of important paragraphs in the evaluation process. Some items have been deleted and some paragraphs added based on the opinion of the arbitrators, it has been taken into account when finalizing the study tool, so check the internal validity of this tool. As the researcher extracted the construction validity of the scale applied on a prospective sample of 47 faculty members, and then calculated the correlation coefficients debugger paragraphs with the measure as whole values, as shown in Table 2. 
Table 2. The values of correlation coefficients (debugger) to items of the study tool

\begin{tabular}{llll}
\hline Item number & Correlation coefficient & Item number & Correlation coefficient \\
\hline 1 & 0.68 & 9 & 0.84 \\
2 & 0.57 & 10 & 0.52 \\
3 & 0.54 & 11 & 0.59 \\
4 & 0.61 & 12 & 0.75 \\
5 & 0.52 & 13 & 0.66 \\
6 & 0.48 & 14 & 0.68 \\
7 & 0.43 & 15 & 0.42 \\
8 & 0.62 & & \\
\hline
\end{tabular}

Notes from the data in Table 2 that the link to the paragraphs of the study tool transaction values ranged between (0.43 - 0.84), all of which are statistically significant values. The researcher has adopted a standard for accepting paragraph that at least linked dimension and a whole list coefficient $(0.30)$. As the researcher calculates the reliability of study tool as a whole using Cronbach's alpha coefficient, reaching $(0.87)$ which is suitable for the use of the tool value for the purposes of the present study also as the researcher sees.

\subsection{Data Analysis}

After collecting the data of the study, the study questions were examined through the following statistical tests:

1) The arithmetic means and standard deviations were used for each paragraph of the study tool, and extraction of the total performance score.

2) To answer the gender differences in college, T-Test was used to these differences.

3) To answer the differences in degrees of trends of faculty members, contrast Four Way ANOVA was used, also (Scheffe-Test) for posterior comparisons was used.

4) The paragraphs of the tool were corrected by giving the paragraphs the following responses grades: $(1=$ Strongly Disagree, $2=$ Strongly Agree, $3=$ neutral, $4=$ Agree, $5=$ strongly agree). Where the grade increases with the arithmetic mean and less class, the less the arithmetic mean, and to judge the degree to which in the light of results and their interpretation, the adoption of three levels as follows: the arithmetic mean (3.75 and above) refers to a high degree. The arithmetic mean (2.50 to less than 3.74$)$ indicates a moderate degree. The arithmetic mean (2.49 or less) refers to a weaker class.

\section{The Results of the Study}

Results related to the first question: "What is the degree of attitudes of faculty members about the process of performance evaluation of public universities?"

To answer this question averages were extracted, standard deviations, and assess the degree of paragraphs that measure the degree of the attitudes of faculty members, and Table 3 show the results.

Table 3. Means, standard deviations, and the degree of attitudes of faculty members through the tool items

\begin{tabular}{|c|c|c|c|c|}
\hline Ranking & Item & Mean & $\begin{array}{l}\text { Standard } \\
\text { deviation }\end{array}$ & $\begin{array}{l}\text { The degree of } \\
\text { performance }\end{array}$ \\
\hline 1 & $\begin{array}{l}\text { The evaluation of the faculty member for himself (self-assessment) in the } \\
\text { performance appraisal process is taken into consideration. }\end{array}$ & 3.74 & 0.81 & Moderate \\
\hline 2 & $\begin{array}{l}\text { Personal factors of the faculty member and his attributes take part from the } \\
\text { performance appraisal process. }\end{array}$ & 3.71 & 0.89 & Moderate \\
\hline 3 & $\begin{array}{l}\text { The tendency to randomness and lack of seriousness by the students in the } \\
\text { performance appraisal process }\end{array}$ & 3.68 & 0.78 & Moderate \\
\hline 4 & $\begin{array}{l}\text { the evaluation process provides feedback for a faculty member to review teaching } \\
\text { methods }\end{array}$ & 3.67 & 0.92 & Moderate \\
\hline 5 & $\begin{array}{l}\text { the performance appraisal process is Characterized by flexibility to face the } \\
\text { changes in teaching }\end{array}$ & 3.66 & 1.01 & Moderate \\
\hline 6 & $\begin{array}{l}\text { The University is reviewing the terms of performance evaluation and its } \\
\text { amendments based on the latest developments and the requirements of the present } \\
\text { time }\end{array}$ & 3.64 & 0.99 & Moderate \\
\hline
\end{tabular}




\begin{tabular}{|c|c|c|c|c|}
\hline 7 & $\begin{array}{l}\text { Research and scientific papers and participation take part of the performance } \\
\text { appraisal process }\end{array}$ & 3.64 & 0.82 & Moderate \\
\hline 8 & $\begin{array}{l}\text { The university benefit from the performance appraisal process in making } \\
\text { appropriate decisions }\end{array}$ & 3.61 & 0.68 & Moderate \\
\hline 9 & $\begin{array}{l}\text { The performance appraisal process of the faculty member has positive results on } \\
\text { the university. }\end{array}$ & 3.58 & 0.71 & Moderate \\
\hline 10 & $\begin{array}{l}\text { There is an ad hoc committee to evaluate the performance of a faculty member and } \\
\text { be within his specialty }\end{array}$ & 3.55 & 0.84 & Moderate \\
\hline 11 & Students have the ability to evaluate a faculty member in the hall assess teaching & 3.54 & 0.90 & Moderate \\
\hline 12 & $\begin{array}{l}\text { The university takes into account when choosing performance standards the job } \\
\text { description for the faculty member }\end{array}$ & 3.51 & 0.69 & Moderate \\
\hline 13 & $\begin{array}{l}\text { performance evaluation process is conducted in regular periodic times (each } \\
\text { semester) }\end{array}$ & 3.49 & 0.60 & Moderate \\
\hline 14 & $\begin{array}{l}\text { The performance evaluation system helps the user to know the strengths and } \\
\text { weaknesses in the performance of a faculty member }\end{array}$ & 3.47 & 0.87 & Moderate \\
\hline \multirow[t]{2}{*}{15} & $\begin{array}{l}\text { The performance evaluation system helps the user to develop and improve the } \\
\text { performance of a faculty member. }\end{array}$ & 3.45 & 0.66 & Moderate \\
\hline & & 3.60 & 0.68 & Moderate \\
\hline
\end{tabular}

* Maximum score (5).

Table 3 shows that the degree faculty members' attitudes were moderate; where the instrument as a whole and all its clauses got responses indicate a medium degree.

Results for the second question: "Is there any statistically significant differences at the significance level $(\alpha=$ 0.05 ) in the attitudes of faculty members depending on the gender variable?"

To see if there were differences between the sexes on the attitudes of the faculty members on the tool, (t-test) was used. Table 4 means and standard deviations and the results of the (T) test.

Table 4. T-Test results of the differences between the mean scores of both sexes the tool of attitudes of faculty members

\begin{tabular}{lccccc}
\hline Tool & Gender & Mean & Standard deviation & T value & Sig \\
\hline \multirow{2}{*}{ Attitudes } & Male & 1.85 & 0.65 & \multirow{2}{*}{2.63} & \multirow{2}{*}{0.009} \\
& Female & 1.97 & 0.52 & & \\
\hline
\end{tabular}

Table 4 shows that the value of $(\mathrm{T})$ reached (2.63) with a statistical significance $(\mathrm{P}<0.01)$, it is evident from the table that the average female degrees higher than the average male degrees.

Results related to the third question: "Is there any statistically significant differences at the significance level $(\alpha=$ 0.05 ) in the attitudes of faculty members depending on the college variable?"

To see if there were differences between the college on the attitudes of the faculty members' tool, (t-test) was used. Table (5) shows means and standard deviations and the results of the (T) test.

Table 5. (T) Test results of the differences between the mean total scores on the tool of attitudes of faculty members

\begin{tabular}{lccccc}
\hline Tool & College & Mean & Standard deviation & T value & Sig \\
\hline \multirow{2}{*}{ Attitudes } & Scientific & 2.35 & 1.27 & \multirow{2}{*}{6.35} & \multirow{2}{*}{$0.000^{* *}$} \\
& Humanitarian & 1.82 & 0.97 & & \\
\hline
\end{tabular}

Table 5 shows that the value of $(\mathrm{T})$ reached (2.63) with a statistical significance $(\mathrm{P}<0.01)$, it is evident from the table that the means of scientific college degrees higher than the mean humanitarian college degrees.

Results related to the fourth question: "Is there any statistically significant differences at the significance level ( $\alpha$ $=0.05$ ) in the attitudes of faculty members depending on the variables of scientific rank, or university, or teaching experience, or age?" 
To answer this question arithmetic means and standard deviations of the estimated faculty member attitudes on the tool items of the study as a whole were extracted, according to the variables (faculty members, Academic Rank, university, teaching experience, age), and Table 6 shows that.

Table 6. Means, standard deviations of the estimated attitudes of faculty members on the tool items on the study as a whole, according to the variables (Academic Rank, university, teaching experience, age)

\begin{tabular}{lcccc}
\hline Variable & Level/category & N. & Mean & Standard deviation \\
\hline \multirow{4}{*}{ Academic rank } & Professor & 58 & 2.66 & 0.70 \\
& Associate professor & 92 & 2.84 & 0.80 \\
& Assistant professor & 103 & 2.92 & 0.57 \\
& Lecturer & 67 & 2.87 & 0.80 \\
University & Al Yarmouk & 110 & 2.88 & 0.64 \\
& Jordan university of Science and & 110 & 2.89 & 0.66 \\
& Technology & 100 & 2.83 & 0.62 \\
Teaching & Al Balqa Applied University & 44 & 3.63 & 0.54 \\
experience & $1-5$ years & 167 & 2.94 & 0.62 \\
& 5-10 years & 109 & 2.82 & 0.63 \\
Age & 10 years and above & 87 & 2.88 & 0.63 \\
& Less than 35 years & 172 & 2.79 & 0.61 \\
\hline
\end{tabular}

It is clear from the Table 6 that there are morphological differences between the estimated means of attitudes of faculty members on the study tool as a whole according to the variables of (Academic Rank, University, Teaching experience, age). To find out the statistical significance of those differences Contrast quartet analysis was used (Four Way ANOVA), and Table 7 shows that.

Table 7. Results of contrast quartet analysis of the estimated attitudes of faculty members on the tool items as a whole, according to the of variables (Academic Rank, university, teaching experience, age)

\begin{tabular}{|c|c|c|c|c|c|}
\hline Source of variance & Sum of squares & Df & $\begin{array}{c}\text { Mean of } \\
\text { squares }\end{array}$ & F value & Sig \\
\hline Academic rank & 0.806 & 3 & 0.269 & 8.116 & $* 0.000$ \\
\hline University & 2.606 & 2 & 1.303 & 2.034 & 0.155 \\
\hline Teaching experience & 2.633 & 2 & 1.317 & 8.398 & $* 0.000$ \\
\hline Age & 2.585 & 2 & 1.293 & 2.835 & $* 0.000$ \\
\hline Error & 84.758 & 310 & 0.273 & & \\
\hline Total & 93.388 & 319 & & & \\
\hline
\end{tabular}

* Statistically significant at the significance level $(0.05=\alpha)$.

As seen from Table 7 there are no statistically significant differences at the level of significance $(0.05=\alpha)$ in the average of estimated attitudes of faculty members on the study tool as a whole according to the study variables except the variable of "university" where it did not show any differences in it.

The table showed no statistically significant differences at the level of significance $(0.05=\alpha)$ in the average of estimated attitudes of faculty members on the study tool as a whole due to the variable "scientific rank", as the value of $(\mathrm{P}=8.116)$, with a statistical value of $(0.000)$. To find out for the benefit of whom those differences was (Scheffe) test for posterior comparisons was used, and Table 8 shows that. 
Table 8. Results of (Scheffe) test of posterior comparisons of the estimated attitudes of the faculty members on the tool items as a whole, according to "scientific rank" variable

\begin{tabular}{|c|c|c|c|c|c|}
\hline & & \multicolumn{4}{|c|}{ Academic rank } \\
\hline & & Professor & $\begin{array}{l}\text { Associate } \\
\text { professor }\end{array}$ & Assistant professor & Lecturer \\
\hline Academic rank & Mean & 2.66 & 2.84 & 2.92 & 2.87 \\
\hline Professor & 2.66 & & & & \\
\hline $\begin{array}{l}\text { Associate } \\
\text { professor }\end{array}$ & 2.84 & 0.31 & & & \\
\hline Assistant professor & 2.92 & 01.00 & 0.30 & & \\
\hline Lecturer & 2.87 & $* 0.47$ & 0.16 & 0.63 & \\
\hline
\end{tabular}

* Statistically significant at the level of statistical significance $\alpha=0.05$ ).

It is clear in Table 8 that there is a statistically significant difference at the level of statistical significance ( $\alpha=$ 0.05 ) between the means of estimated attitudes of faculty members with scientific rank (professor) on the one hand and with Academic Rank (lecturer) on the other hand, for the benefit of faculty members with Academic Rank (lecturer).

The table also showed no statistically significant differences at the level of significance $(0.05=\alpha)$ in the means estimated attitudes of faculty members on the study tool as a whole due to the variable Teaching experience, as the value of $(\mathrm{P}=8.398)$, with a statistical significance $(0.000)$. To find out for the benefit of whom those differences (Scheffe) test for posterior comparisons was used, and Table 9 shows that.

Table 9. Results of (Scheffe) test for posterior comparisons pf the estimated attitudes of faculty members on the tool items as a whole, according to the teaching experience variable

\begin{tabular}{lcccc}
\hline \multirow{2}{*}{ Number of students in the class } & & \multicolumn{3}{c}{ Number of students in the class } \\
\cline { 3 - 5 } & Mean & $1-5$ years & $5-10$ years & 10 years and more \\
\cline { 3 - 5 } & 3.36 & & 2.94 & 2.82 \\
\hline 1-5 years & 2.94 & 0.10 & & \\
$5-10$ years & 2.82 & $* 0.70$ & 0.09 & \\
10 years and more & & & \\
\hline
\end{tabular}

Table 9 showed that there is a statistically significant difference at the level of $(\alpha=0.05)$ between the mean of estimated attitudes of faculty members whose teaching experience is (1-5 years) on the one hand, and those with a teaching experience (10 years and over) on the other hand, and in favor of teaching experience (1-5 years).

The table also showed statistically significant differences at the level of significance $(0.05=\alpha)$ in the average of estimated attitudes of faculty members on the items of the study tool as a whole due to the age variable, as the value $(\mathrm{P}=2.835)$, with a statistical significance of $(0.000)$. To find out for the benefit of whom those differences (Scheffe) test for posterior comparisons was used, and a Table 10 shows that.

Table 10. Results of (Scheffe) test for posterior comparisons of the estimated attitudes of faculty members on the tool items as a whole, according to the "Age" variable

\begin{tabular}{lcccc}
\hline & \multicolumn{3}{c}{ Number of students in the class } \\
\cline { 3 - 5 } & & Lean than 35 & From 35-45 & More than 45 \\
\cline { 3 - 5 } & 2.88 & & 2.79 & 2.29 \\
\hline Less than 35 & & & \\
From 35-45 & 2.79 & 0.05 & & \\
More than 45 & 2.29 & $* 0.85$ & 0.15 & \\
\hline
\end{tabular}

Table 10 showed that that there is a statistically significant difference at the level of $(\alpha=0.05)$ between the mean of faculty members' attitudes on the study tool as a whole due to the Age variable from (less than 35 years old). And with those of (more than 45 years) age on the other hand and in favor of those with age (less than 35 years 
old).

\subsection{Discussion of the Results}

The researcher attributed the result of the first question to the fact that the faculty members believe that the performance evaluation is not objective. especially when it comes from the students because of the low level of trust between them; and they cannot judge a faculty member as non-qualified and trained for the evaluation process although they were closer to it through lectures and through their interaction and it faces them academically, where it affects the personal relationships and supports the grades for subjects. The researcher also attributed this result to the fact that universities do not take into account the positive and negative incentives after the results of the performance appraisal process, and the performance appraisal process becomes annual routine and loses its luster with the passage of days. Universities do not bother doing interviews after the performance evaluation process to provide an opportunity for faculty members to discuss the evaluation results and determine the future goals between the university and a member employed in it. This result is consistent with the study of Razek (2006), which sees the student assessment and colleague came the last rank because of the lack of attention to it.

The researcher believes that female faculty members are seeking to support the scientific status in the field of specialization, which reflects a deep desire to prove oneself and have academic success. The difference between the sexes arising from the reservation and females resulting from the difference in socialization exercised by parents in the home and the educators at the school according to gender, since the childhood stage the parents' demands from females to be reservation and compliance with social standards. Females are more disciplined in the administrative matters relating to the process of improvement and development work, they are initiatives and they look at things more deeply than males who may tend to indifference sometimes. This result is consistent with the study of Razek (2006) that females are more interested in the evaluation process.

Regarding the attitudes of faculty members about performance evaluation which depends on the College variable, the researcher attributed these differences to the fact that faculty members at scientific faculties have more awareness and attention to the skills, and more teaching competencies from faculty members at other colleges. The theoretical courses at the scientific colleges may be more difficult and more abstract from the courses of the rest of the colleges. In addition, the use of English in the teaching of the courses at the faculties of science and engineering which requires students from these colleges a larger effort to understand these courses. Compared to the effort required of the humanitarian faculties, social sciences, which use the Arabic language in the teaching of courses which are almost too abandoned the complex mathematical methods. this would lead to a humanitarian college students estimated to be less than scientific college students estimates of the performance of faculty members, as the researcher attributed these differences to the faculty the humanitarian faculties of social Sciences members may not have the sufficient and serious process of valuation concerns. And the result of this study differs from the study of Jeffry (2002), there are differences in the responses of the students and in favor of humanitarian faculties.

The researcher believes that the lecturer got the difference because he is interested in assessing students, and achieves his desires, and gain satisfaction of being at the beginning of his career within the university; which reflected on the teaching methods and style of communication with students. Unlike the teachers who are at higher academic rank such as Professor and associate professor who reach a level that cemented his status within the university and they reject performance evaluation and its use in decision-making, to consider that students or others are not qualified to assess those in their level. The lower degree of faculty members, the more favorable to be assessed by others, the lecturer looks at the performance evaluation process with interest to see the weaknesses of his development in order to keep the position he reached. The result of this study differs with the study of Ajlouni (2011) that indicated no differences in academic rank.

For those with teaching experience less than 5 years, they gain a statistical significance who perceive the evaluation process. The researcher attributed this it will provide them with the weaknesses and they need to succeed and grow, excellence and speed of proving the presence, in addition to providing them with what is new in the global, they are looking for help to raise their level and improve their needs and increase their self-confidence. Faculty members with vast experience in their field do not look at performance appraisal because they exceeded this stage years ago. While individuals with limited experience, who are less than 5 years, still at work have less social interaction with old teachers. This makes them less consensus which reduces preference for evaluating colleagues, and that with the experience and the passage of time the faculty members acquire self-esteem and mastery of the art of scientific confidence and also there are no longer interested in colleagues' assessing. In addition, experienced teacher have good relations with co-workers, therefore, there is 
no fear from his evaluation. On the other hand, those teachers who are with long years of experience are familiar with this type of assessment given that they are assessed through promotions committees that evaluated the quantitative and qualitative aspects of the research and scientific activity when promoted to the rank of professor or associate professor. The result of this study differs from the study of Ajlouni (2011), which pointed to the lack of differences in the experience of teaching.

The researcher believes that teachers with younger age (less than 35 ) by virtue of their closeness to the students, and form strong personal relationships with each other, care about performance evaluation by students more than others older who are proud of their knowledge. Since and they see that there is no one better than their experience, and that there is no benefit from this assessment, and that this process is a loss of prestige of the faculty member. And the result of this study differs from the study of Ajlouni (2011) that indicated no differences in age.

\subsection{Recommendations}

In light of the above findings, the researcher recommends:

1) Departments of universities have to give courses and establish awareness meetings for faculty members show the importance of students' assessment of the faculty member and the university's reliance on this assessment.

2) The assessment process must be in an orderly and generally accepted process in terms of target and time by a faculty member.

3) Not giving the student' evaluate the bulk of the fate of the faculty member's report, but the distribution of the assessment on several things such as activities, research, and others.

4) Keep types of assessment (peer-assessment, and management's assessment, self-assessment) seriously.

5) Conduct similar studies concerned with the process of performance assessment on other samples and universities.

\section{References}

Abdel Razek, W. (2006). Trends of faculty members of the College of Education, King Saud University, about the methods of evaluating their performance. XIII Annual Meeting (teacher preparation and development in the light of contemporary variables), the Saudi Society for Educational and Psychological Sciences (Justin), College of Education, King Saud University, Riyadh.

Abdul Baqi, S. (2000). Human Resource Management. Amman: University House Publishing.

Abu Madi, K. (2007). Obstacles to the performance evaluation of employees in the Palestinian universities and ways of treatment (Unpublished MA thesis). Faculty of Commerce, the Islamic University of Gaza

Abu Sheikha, N. (2000). Human Resource Management. Amman: Dar Al Safa for publication and distribution.

Aguinis, H. (2007). Performance management. London: Printice Hall.

Ajlouni, M. (2011). Trends of faculty members at Jordan University of Science and Technology about the process of student assessment for them: a field study. Journal of the Federation of Arab Universities Educational Psychology, 9(4), 191-206.

Al Sabah, A. (1997). Administrative control standards: standards, assessment, correction. Amman: Dar Zahran.

Argon, T. (2010). A Qualitative Study of Academicians' Views on Performance Evaluation, Motivation and Organizational Justice. International Online Journal of Educational Sciences, 2(1), 133-180.

Armstrong, M., \& Baron, A. (2005). Managing Performance: Performance management in action. London: CIPD.

Aslam, H. (2011). Performance evaluation of teachers in universities: Contemporary issues and challenges in Pakistan. Proceedings of the 2011 International Conference on Teaching, Learning and Change. (c) International Association for Teaching and Learning (IATEL): 339-362.

Bascal, R. (1999). Performance Management. USA: McGraw-Hill.

Buendía, L. (1996). La investigación sobre evaluación educativa. Revista de Investigación Educativa, 14(2), 4-24.

Carreras, J. (2005). El concepto de competencia y el diseño de planes de estudio a partir de perfiles competenciales. Dos cuestiones que hay que aclarar en el marco de las EEES. In El Debate sobre las 
competencias a la enseñanza universitaria (pp. 8-25). Barcelona: ICE UB.

Centra, A. (1993). Reflective faculty evaluation: Enhancing teaching and determining faculty effectiveness. San Francisco: Jossey-Bass.

Cokins, G. (2004). Performance Management. John Wiley \& Sons, Hoboken.

Davies, M., Hirschberg, G., Lye, N., Johnston, C., \& McDonald, M. (2007). Systematic influences on teaching evaluations: The case for caution. Australian Economic Papers, 46(1), 18-38. https://doi.org/10.1111/j.1467-8454.2007.00303.x

Ellis, L., Burke, M., Lomire, P., \& McCormack, R. (2003). Student grades and average ratings of instructional quality: The need for adjustment. The Journal of Educational Research, 97(1), 35-40. https://doi.org/10.1080/00220670309596626

Filimban, A. (2007). Academic Profile for evaluating the job performance of faculty members at King Abdulaziz University. A paper presented to the seminar "Development of the teaching staff members in higher education institutions of the" challenges and development.

Garcia, M., \& Congosto, E. (2000). Evaluación y Calidad del Profesora-do. In T. González Ramírez (Ed.), Evaluación y Gestión de la Calidad Educa-tiva. Un Enfoque Metodológico (pp. 127-157). Málaga: Aljibe.

Greer, R. (2001). Strategic human resource management: A general managerial approach (2nd ed.). London: Printice Hall.

Hassan, M., \& El-Khouly, M. (2003). Student Assessment of the teaching performance of the faculty member at the University of Qatar and its relationship with some variables, Educational Research Center at the University of Qatar. Retrieved from http://www.khayma.com/education-technology/Sharing8.htm

Ibrahimi, N. (2013). The role of university in the development of human capital to achieve sustainable development (A case study of Al Maseelah University) (Unpublished Master thesis). Farahat Abbas University. Algeria

Jufairi, E. (2002). The views of graduate students in the teaching performance of faculty members at the University of Umm Al-Qura. The educational magazine, 16(64), 111-152.

Khoury, G. (2004). Innovative management model for Performance Appraisal: the case of the Palestinian Public Universities. Journal Management Research News, 27, 56-73. https://doi.org/10.1108/01409170410784356

Koontz, H., \& Weihrich, H. (2005). Essentials of Management: An International Perspectives (6th ed.). New York: McGraw-Hill.

Kubaisi, A. (2010). The reality of the quality of university teaching and ways to elevate it. Retrieved from http://www.isst.org/index.php

Maher, A. (1999). Human Resource Management. Cairo: University House printing, publication, and distribution.

Marqués, M. (2008). Una experiencia madura de innovación educativa. In Jornadas Nacionales sobre Estudios Universitarios de los Proyectos de Convergencia a la Realidad de los Nuevos Títulos. Universidad Jaume I.

Moreno-Murcia, J., Torregrosa, Y., \& Pedreno, N. (2015). Questionnaire evaluating teaching competencies in the university environment. Evaluation of teaching competencies in the university. New Approaches in Educational Research, 4(1), 54-61. https://doi.org/10.7821/naer.2015.1.106

Nono, N. (2004). The performance evaluation policies of employees in government institutions of higher education in the Gaza Strip (Unpublished MA thesis). Faculty of Commerce, the Islamic University of Gaza. P. $32 \mathrm{Al}$ Zarqa University Conference (2014).

O'Keefe, J. (2002). Persuasion: Theory and research (2nd ed.). Thousand Oaks, CA: Sage Publications.

Pallisera, M., Fullana, J., Planas, A., \& del Valle, A. (2010). La adaptación al espacio europeo de educación superior en España. Los cambios/retos que im-plica la enseñanza basada en competencias y orientaciones para responder a ellos. Revista Iberoamericana de Educación, 52(4), 1-13.

Peterson, D. (2000). Teacher evaluation: A comprehensive guide to new directions and practices (7th ed.). CA: Corwin, Thousand Oaks.

Reddy, K. (2006). University Administration (1st ed.). New Dehli: Omega Publications.

Safdar, M. (2009). Public and Private Universities in Pakistan. The News [Pakistan], 12 May. 
Salem, M., \& Saleh, A. (2002). Human Resource Management. Irbid: the world of modern books for publication and distribution.

Salmerón, L. (2013). Activities that promote transfer of learning: A review of the literature. Revista de Educación, special issue 2013.

Seldin, P. (1980). Successful faculty evaluation programs: A practical guide to improve faculty performance and promotion/tenure decisions. Curgers: Conventry press.

Shaheen, M. (2010). The effectiveness and fairness of the performance of employees in the Palestinian universities and assess its impact on job performance and organizational loyalty and systematic trust (Unpublished MA thesis). Faculty of Commerce, the Islamic University of Gaza.

Shawish, M. (2005). Human Resource Management. Shurooq: personnel management.

Sheikh, H. (2007). Evaluation of the Teachers by the High Ups, By the Students, By the Peers and Self-Assessment. Paper presented at National Conference on Professional Development of Teachers in Higher Education in Pakistan, Islamabad, Pakistan,16-18 January, pp.18-21.

Skelton, A. (2005). Understanding Teaching Excellence in Higher Education: Towards a Critical approach. London: Routledge. https://doi.org/10.4324/9780203412947

Skerritt, Z. (1992). Professional Development in Higher Education: A Theoretical Framework for Action Research. London: Kogan Page.

Stronge, J. H. (1995). Balancing individual and institutional goals in educational personnel evaluation: A conceptual framework. Studies in Educational Evaluation, 21, 131-151. https://doi.org/10.1016/0191-491X(95)00010-R

Stronge, J. H. (2006). Evaluating Teaching (2nd ed.). California: Corwin Press, https://doi.org/10.4135/9781412990202

Tejedor, J., \& García-Valcárcel, A. (1996). Evaluación institucional en la Universidad. Revista Galega de Pisopedagoxia, 6, 101-146.

Wilson, P. (2005). Human Resource Development (2nd ed.). London: Kogan Page.

\section{Copyrights}

Copyright for this article is retained by the author(s), with first publication rights granted to the journal.

This is an open-access article distributed under the terms and conditions of the Creative Commons Attribution license (http://creativecommons.org/licenses/by/4.0/). 